\title{
Homéopathie et/ou allopathie ? Les techniques de diagnostic dans l'articulation des cadres de référence
}

Emilie Gomart

\author{
(2) OpenEdition \\ Journals \\ Édition électronique \\ URL : https://journals.openedition.org/tc/509 \\ DOI : $10.4000 /$ tc. 509 \\ ISSN : 1952-420X \\ Éditeur \\ Éditions de l'EHESS
}

Édition imprimée

Date de publication : 1 mars 1996

ISSN : 0248-6016

Référence électronique

Emilie Gomart, " Homéopathie et/ou allopathie ? Les techniques de diagnostic dans l'articulation des cadres de référence », Techniques \& Culture [En ligne], 25-26 | 1996, mis en ligne le 28 octobre 2005, consulté le 29 septembre 2022. URL : http://journals.openedition.org/tc/509; DOI : https://doi.org/ $10.4000 /$ tc. 509

Ce document a été généré automatiquement le 29 septembre 2022.

Tous droits réservés 
Homéopathie et/ou allopathie? Les techniques de diagnostic dans l'articulation des cadres de référence

Emilie Gomart 